\title{
The Ethical Dimension of Canadian Commemoration Controversies
}

\author{
Lindsay Gibson \\ Department of Elementary Education \\ Faculty of Education \\ University of Alberta \\ lgibson@ualberta.ca
}

Many Canadians expected that the summer of 2017 would be a time of celebration for Canada 150, the sesquicentennial anniversary of Canadian Confederation, but few could have anticipated that it would be the year that commemoration controversies were thrust onto the main stage of public debates. In addition to the contentious arguments about the celebration of Canada 150 , there have been, and continue to be, vigorous debates about whether commemorations of controversial historical figures such as Hector Langevin, Egerton Ryerson, Joseph Trutch, Nicholas Flood Davin, Mathew Baillie Begbie, Edward Cornwallis, and Sir John A. Macdonald should be renamed, altered, or removed.

Such debates are central to the ethical dimension of history, one of six historical thinking concepts included in Seixas' historical thinking model (2009; 2017). For Seixas, the ethical dimension imbues the study of history with meaning and expands individuals' historical consciousness by helping them learn from ethical transgressions in the past, judge the past more fairly, and better handle present and future ethical dilemmas (Seixas \& Morton, 2013, p. 170). Thus, the ethical dimension involves making reasoned ethical judgments about past actions of historical individuals or groups, assigning blame or credit to historical individuals or groups for their actions, and determining what obligations or responsibilities those in the present have for remembering or responding to the contributions, sacrifices, and injustices of the past (Seixas \& Morton, 2013, p. 170-171).

In this article I provide a series of questions drawn from Seixas' articulation of the ethical dimension to provide a framework for educators, students, and members of the public to think historically about commemoration controversies and make reasoned ethical judgments about how to respond. ${ }^{1}$ Throughout the article I use the Davin School renaming controversy to expand on the questions that should be considered when making reasoned ethical judgments about historical commemorations.

\section{The Davin School Renaming Controversy}

Recently there have been calls to rename the Davin School, an elementary school in Regina, Saskatchewan. Built in 1929, the school was named after Nicholas Flood Davin, who in 1879 wrote an influential report that led to the creation of the system of government that funded residential schools in Canada. The issue of renaming the Davin School was first raised in 2016 in response to the Calls to Action of the Truth and Reconciliation Commission (Davis, 2017). Since

\footnotetext{
${ }^{1}$ It is important to note that decisions about what should be done about commemorations are central to the ethical dimension, however, the other five historical thinking concepts (i.e., historical significance, continuity and change, cause and consequence, and historical perspectives) included in Seixas' historical thinking model are also important for thinking historically about commemorations.
} 
this time, the issue has been discussed by the Regina Public School Board (RPSB), the Davin School community council, and in several media articles (Martin, 2017; Richards, 2016; Spooner, 2016). Those who argue the Davin School should not be renamed suggest that renaming denies the complexity of Canadian history, and that removing Davin's name would erase him from history. They also argue that Davin's views were common for the time and renaming is presentistic because it imposes contemporary values on the past (Richards, 2016). Those who argue that the school should be renamed claim that Davin is not an ideal or inclusive role model for students to emulate, and if we are going to move towards a more just future, we must face the difficult past that he embodies (Spooner, 2016). To deliberate on this issue, the RPSB has initiated a process that includes seeking guidance from its Elders' Advisory Council, establishing an online consultation process to gather public feedback, and providing more public information related to Davin's historical legacy (Davis, 2017). The school board has agreed to make a final decision on whether they will rename the Davin School by the end of the 2017/2018 school year.

\section{Thinking Historically about the Ethical Dimension of Commemoration Controversies}

In this section, I outline five questions to consider when making reasoned ethical judgments about historical commemoration controversies. Throughout this process, I refer to the Davin School renaming controversy to illustrate key areas to consider when responding to each question.

1. Were the actions taken by the person or group acceptable given the values, attitudes, and beliefs that existed in society at the time? Would the actions taken by the person or group be acceptable given the values, attitudes, and beliefs that exist in contemporary society today?

In order to overcome the problem of presentism when making ethical judgments Gaddis (2002) suggests that it is important to "triangulate the past" by accepting our engagement with contemporary morality, but also to distinguish this from the morality of the time being considered (p. 126). On January 28, 1879, Prime Minister John A. Macdonald appointed Nicholas Flood Davin to report on Industrial Schools in the United States to determine whether similar schools should be established in the North-West Territories of Canada (Thompson, 1994). Davin submitted The Report on Industrial Schools for Indians and Half-Breeds (also known as the Davin Report) on March 14, 1879, in which he concluded that the Canadian government should establish a system of government-funded, church-run, Indian boarding schools. When responding to the above questions, it is necessary to consider whether Davin's recommendation to establish a system of residential schools was acceptable given the values, attitudes, and beliefs at the time, and compare this with how acceptable these recommendations would be today. In making this judgment it is important to determine how common Davin's beliefs about Indigenous people were for different individuals and groups in Canadian society, not just white European male settlers.

2. To what degree was the person or group being commemorated responsible for the historical events that took place? 
Assigning historical responsibility is a particular kind of ethical judgment that allocates blame or credit to an historical individual or group, and is not the same as determining who caused a historical event to occur (Stipp, Gibson, Denos, Case, \& Miles, 2017). When deciding if Davin was responsible for creating the system of government funded residential schools in Canada, it must be decided if he was in a position of power or authority to make the decision, as well as affect the outcome of the decision. Noting that Davin undoubtedly recommended that residential schools should be established, a key question to consider is how influential the report was, and to what extent Davin was in a position of authority to make the decision to establish residential schools.

3. Should the event, person, or group be commemorated and memorialized given its historical legacy? Is the event, person, or group's historical legacy aligned with the values, beliefs, and values of the community where the commemoration is located?

In simple terms, historical legacies are what we remember about an individual or group; but determining the historical legacy of an individual, group, or event is not an easy task. Worsfold (2017) explains that historical actors do not have one "principal legacy", and peoples' perspectives, values, beliefs, and values influence their conclusions about the principal legacy of individuals. Although Davin has been primarily remembered in recent years as the author of the Davin Report, his historical legacy is much more complicated than this. He was a skilled orator, author, poet, and playwright, and was a journalist and founder of the Regina Leader newspaper that still exists as the Regina Leader-Post today. He was a politician who won the seat of Assiniboia West in the 1887, 1891, and 1896 federal elections, and some have called him "The Father of Western Canada" (Richards, 2016). Although Davin played a minimal role in achieving responsible government in the North-West Territories, or provincial status for Saskatchewan, he was known as an advocate of French language rights in the North-West and for women's rights (Thompson, 1994). Davin also struggled with depression and alcoholism throughout his life, and killed himself with a pistol less than a year after narrowly losing his seat in the 1900 election.

After determining the nature of Davin's historical legacy, the Davin School community, the RPSB, and the people of Regina must decide if his legacy is aligned with their identified values. For example, according to RPSB policy, schools are to be named "in recognition of contributions to education of individuals associated with this community, special events of historical significance, and geographical features in the Regina area" (Martin, 2017). Given Davin's complicated legacy, a key area of deliberation involves deciding whether his actions contributed to the education of individuals in the community, and the extent to which he was involved in events of historical significance that deserve commemoration.

4. Does the commemoration of the event, person, or group negatively affect individuals or groups in the community where the commemoration is located?

In making the decision about renaming the Davin School, community members should consider whether keeping the Davin School name, or removing the name, would negatively impact individuals or groups in the community. On the surface, it seems that no one, except perhaps Davin's descendants, would be negatively affected by removing his name from the school. 
However, there is a need to consider whether an Indigenous person, a residential school survivor, or their relatives would be negatively affected by attending or visiting a school named after a man that played a role in creating the system of residential schools that caused intergenerational trauma for so many Indigenous people.

5. Should the commemoration of the event, person, or group be kept as is, revised, or removed?

In making this final decision, community members must consider their responses to the previous questions, but also deliberate about the benefits and limitations of keeping his name, or removing it and replacing it with a new name. Richards (2016) maintains that removing Davin's name from the school would erase him from history and deny people an opportunity to learn about the complicated nature of Canadian history. Richards suggests that Davin's name should be kept on the school, but a plaque or other interpretive marker that highlights Davin's complex legacy should be installed. Alternatively, Spooner (2016) suggests that the school should be renamed, but Davin's historical legacy should continue to be commemorated at the school so that his history is not forgotten.

If it is determined that Davin's name should be removed from the school, community members should decide what steps, if any, should be taken to ensure that the community continues to learn about, and from Davin's historical legacy. If it is determined that Davin's name should be kept on the school, community members should decide what steps could be taken to ensure that Davin's actions and legacy are properly contextualized and explained.

\section{Conclusion}

In many ways, identifying the questions for thinking historically about the ethical dimension of commemoration controversies is the easy part. Analyzing the evidence, formulating conclusions for each question, and arriving at a final decision about what should be done is the challenging part. Ultimately, the questions are meant to provide a framework for community members, as well as students and educators, to engage in continued conversations about renaming the Davin School in order to arrive at a solution that is equitable for all.

\section{References}

Davis, A. M. (2017, September 7). Public input sought on Davin school name change. Regina Leader-Post. Retrieved from http://leaderpost.com/news/local-news/public-to-helpdecide-future-of-davin-school-name

Gaddis, J. L. (2002). The landscape of history: How historians map the past. Oxford: Oxford University Press.

Martin, A. (2017, August 25). Parents urge education amid discussions of renaming Regina's Davin School. Regina Leader-Post. Retrieved from http://leaderpost.com/news/localnews/parents-support-education-amid-discussions-of-renaming-reginas-davin-school 
Richards, T. (2016, April 18). Explore Nicholas Flood Davin's controversial life, but don't erase his name from school. Regina Leader-Post. Retrieved from http://leaderpost.com/opinion/columnists/explore-nicholas-flood-davins-controversiallife-but-dont-erase-his-name-from-school

Seixas, P. (2009). A modest proposal for change in Canadian history education. Teaching History, 137, 26-30.

Seixas, P. (2017). A model of historical thinking. Educational Philosophy and Theory, 49(6), 593-605.

Seixas, P., \& Morton, T. (2013). The big six historical thinking concepts. Toronto, Canada: Nelson Education.

Spooner, M. (2016, January 28). Nicholas Flood Davin's legacy needs a second look. Regina Leader-Post. Retrieved from http://leaderpost.com/opinion/letters/nicholas-flood-davinslegacy-needs-a-second-look

Stipp, S., Gibson, L., Denos, M., Case, R., \& Miles, J. (2017). Teaching historical thinking: Revised and expanded edition. Vancouver, Canada: The Critical Thinking Consortium.

Thompson, J. H. (1994). Nicholas Flood Davin. Dictionary of Canadian Biography. Volume XIII (1901-1910). Retrieved from http://www.biographi.ca/en/bio/davin nicholas flood 13E.html

Worsfold, E. (2017, July 18). The politics of reclaiming, not renaming. Retrieved from http://activehistory.ca/2017/07/the-politics-of-reclaiming-not-renaming/ 